$\begin{array}{ll}\text { ECHOGEO } & \text { EchoGéo } \\ & 20 \mid 2012 \\ \text { Des mobilités aux transports. Regards croisés en } \\ \text { Afrique de l'ouest }\end{array}$

\title{
The West African port system: global insertion and regional particularities
}

Jean Debrie

\section{OpenEdition}

Journals

Édition électronique

URL : https://journals.openedition.org/echogeo/13070

DOI : $10.4000 /$ echogeo. 13070

ISSN : 1963-1197

Éditeur

Pôle de recherche pour l'organisation et la diffusion de l'information géographique (CNRS UMR 8586)

Référence électronique

Jean Debrie, "The West African port system: global insertion and regional particularities ", EchoGéo

[En ligne], 20 | 2012, mis en ligne le 13 juillet 2012, consulté le 10 août 2021. URL : http://

journals.openedition.org/echogeo/13070; DOI : https://doi.org/10.4000/echogeo.13070

Ce document a été généré automatiquement le 10 août 2021.

EchoGéo est mis à disposition selon les termes de la licence Creative Commons Attribution - Pas

d'Utilisation Commerciale - Pas de Modification 4.0 International (CC BY-NC-ND) 


\title{
The West African port system: global insertion and regional particularities
}

\author{
Jean Debrie
}

\section{Port networks: a global change and regional transpositions}

1 The spread of containerization to all the world's maritime ranges has been accompanied by a change in the morphology of the networks that serve ports. Shipping lines and container terminal operators have thus developed a global network based on the hub and spoke system. This has created a new classification of ports, consisting of hinterland ports serving localized markets, transhipment ports, where a number of different shipping lines operate and carry out freight transfers, and combined ports which perform both functions (serving markets and reorganizing shipping routes). The development of the global network is thus based on the principles of port concentration and the hierarchical operation of shipping lines (Ducruet \& al, 2011). There is an abundant academic literature on this network morphology (Fleming, 1994), on the change in port function from serving markets to performing transhipment (Gouvernal \& al, 2009), and on the strategies of the international operators who are creating this new network (Frémont, 2007; Parola \& al, 2008). This change goes hand in hand with globalization and therefore involves corporate affairs. Its basis is a trend towards "terminalization" to use the term coined by Brian Slack (2005), that is to say the transformation of ports into a set of interconnected terminals that operate within a global network that is structured by the strategy of a small number of international operators.

2 The increase in the number of port concessions in the world in varied contexts of deregulation has permitted the break-up of ports into terminals and led to a change in the nature of the relationship between networks and the areas they serve. However, 
although the change in the network is a general phenomenon, it nevertheless takes different forms in different port ranges depending on the economic, political, and technical characteristics of the areas that are served. In order to understand a port system it is therefore necessary to explain the connection between the new types of maritime and port networks (a global hub and spoke network) and the way it is implemented in areas with specific regional and local features. Considering ports in their contexts provides a way of understanding the interplay between organizational factors (network morphology), institutional factors (regulation) and geographical factors (the characteristics of the area served by the port). The aim of this paper is to observe this combination of factors at work in the West African port system. West Africa occupies a marginal position in the economic system, but nevertheless provides a striking illustration of the changes that are occurring as a result of globalization and the deregulation of transport networks. The development of the region's ports is taking place within a process of integration within the global network (Part 1) which nevertheless requires the operators to adapt to the characteristics of the West African space (Part 2). The changes that are occurring in ports within the regional space reveal the presence of an operator geography which is changing or how areas are served.

\section{Changes in West African ports: towards terminalization?}

\section{The colonial past and extraversion: a brief survey of port history}

The make-up of the West African port range was originally determined by colonial exploitation and subsequently consolidated by economic extraversion which determines the structure of trade. This is a well-known process that has been described by a number of geographers (Taaffe \& al, 1963; Hoyle \& Charlier, 1995; Debrie, 2010). Maritime transport was the means by which the European empires achieved continuity. It relied on the development of port infrastructure, which was served by railways and a network of tracks that made it possible to exploit the colonies. Although the ports and the inland routes permitted colonial exploitation it is important to note that the system was set up with a minimum of investment. The heritage of this historical period therefore consists of a small number of ports with poor facilities and a few railway lines that were not linked to each other and which enabled the competing colonial powers to carry out their export activities (for example, peanuts on the Niger/Dakar route, bananas on the Niger/Conakry route, coffee, cocoa and timber on the Niger/Abidjan route, and cotton, cocoa and mining products on the Gold Coast/Cape Coast routes). This initial system of ports was subsequently consolidated by the planning policies of the independent States. The ports were used by national economies to serve their regions by means of the historical railway lines alongside which roads were gradually built that formed an increasingly comprehensive national road network. The colonial epoch followed by the early days of independence produced infrastructure (ports and inland roads and railway lines) which matched the dominant economic structure of the areas served (extraversion). They are the first two stages of the way successive political authorities planned the path ports would follow. This way is similar in all area with a colonial past. In different areas in Africa (Maghreb, South Africa, East Africa), port 
cities have a polarization function in regional economy and spatial organization (Mohamed-Chérif \& al, 2011).

Figure 1 - Ports and inland links (2007)

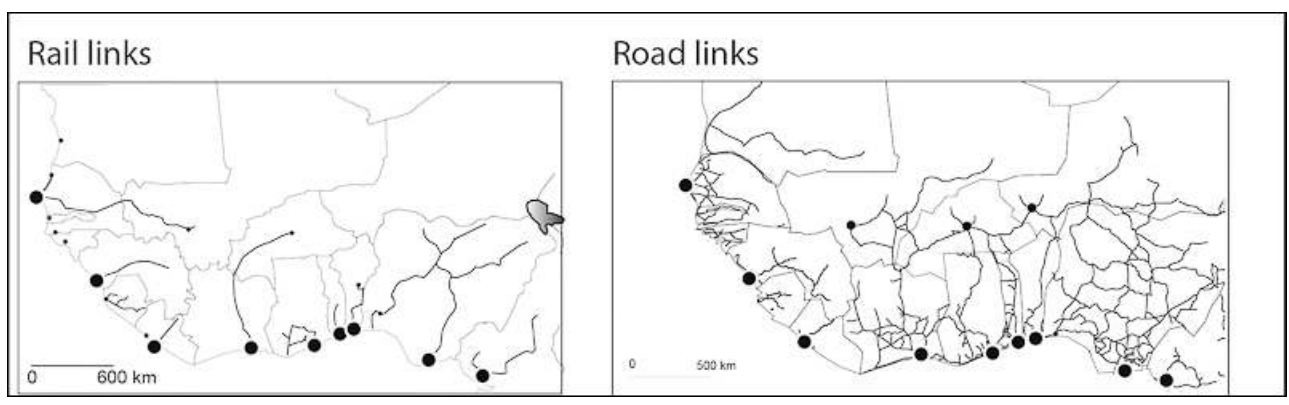

Source: Michelin Map, n`953 - 2007

\section{The period of structural adjustment. Transport deregulation or opportunities for firms}

The 1980s marked a break with these planning operations and the start of a new phase of deregulation characterized by the withdrawal of the public authorities. In a context of crisis and debt, two major global organizations (the IMF and the World Bank) put in place structural adjustment plans which were approved and accepted throughout what is known as the international aid sector, i.e. at multilateral and governmental levels. These plans targeted the financial and macroeconomic context in the case of the IMF and the economic and sectoral context in the case of the World Bank and have divided the various areas of society and the economy into different sectors. In all cases, these sector-specific projects share the same underlying principle of reducing the scale of public involvement and increasing the presence of the private sector in increasingly deregulated sectors of the economy. In every West African country, Transport Sector Projects (TSP) have thus increased the role of the private sector in the transport and public works industries and revised the regulatory frameworks to permit the advent of the private sector within a so-called "priority" regional network (Lombard, 1999). The ports, which provide the entry and exit points to this network, were opened up to competition at the same time as the widespread application of a Build, Operate, Transfer (BOT) concessionary system advocated by the World Bank. From the end of the 1980s, this network was to attract international investors who aimed to guide the ports towards new service strategies with support from international donors who focused their aid on the main infrastructure network and therefore the routes leading to and from ports.

In this context, the 1980s and 1990s saw the massive involvement of the Bolloré and Maersk-Sealand groups in the full range of activities related to port services. This involvement first of all reflected the Bolloré group's strategy that it developed very early, in the mid-1980s. As the result of a sequence of takeovers, the activities of the group (which now operates under the single banner of Africa Logistics) are centred on the ports. Its activities range from port handling to rail operation and also include the management of inland terminals. This business model, which was launched by a series of takeovers (SCAC, SAGA...) and strengthened by a number of concessions for 
operating ports (Abidjan, Lagos, Tema ...) and railway services (Sitarail, Camrail) and then more recently by the development of inland terminals (Bamako, Sikasso...), enables the company to offer integrated door-to-door services (transport, freight handling, administrative formalities) to a number of destinations from the ports. What is important here is not so much the detailed nature of the set-up, but the process of vertical integration involved, which has its basis in the desire to organize a hierarchical network around a small number of routes.

The advent in the 1990s of the world's largest shipping line, Maersk-Sealand, duplicated Bolloré's set-up and produced a type of duopoly for services to the main ports. Maersk-Sealand's presence dates back to 1986 when it started to operate at Dakar, Abidjan and Lomé. From 1992 it began to implement an effective strategy of integration, after the Bolloré group's conviction under European law for noncompetitive practices. Gradually, Maersk-Sealand developed a set-up similar to Bolloré's, at times operating port and inland terminals as a joint venture with Bolloré (Abidjan, Douala, Tema) or in competition with it. It served the West African coast as a shipping line, operated port terminals through its freight handling subsidiary AP Moller, and increasingly also performed inland transport via its logistics subsidiary DAMCO (Le Mens, 2011).

\section{Towards terminalization? The spread of port concessions}

7 Recent years (2005-2010) have witnessed a third stage of development, characterized by the spread of port concessions leading to a broadening of competition. It marks the renewed presence of the private sector in the operation of terminals. Maersk-Sealand and Bolloré still dominate port activities - the new port concessions at Tema, Lagos, Pointe Noire, Abidjan and Conakry have been allocated to Bolloré and/or AP Moller, the Maersk-Sealand group's freight-handling subsidiary (Figure 2). Port activities are therefore characterized by a dual process of competition and cooperation between the two groups which strengthen their capabilities by extending their operations to new ports. An illustration of this gradual process of extension is given by AP Moller's acquisition of the concession for the port of Monrovia in Liberia in 2010. But the recent arrival on the West African coast of the international port terminal operator Dubai Ports World (Dakar), and of the shipping line the Mediterranean Shipping Company (Lomé) and port terminal development projects at Onne in Nigeria by the shipping line China Ocean Company and at Sao Tomé Principe by the French shipping line CMA-CGM, bear witness to rising competition at ports in the context of a classical process of port terminalization that is currently taking place in maritime networks (Figure 2). African ports display obviously different profiles in the institutional organization. In a recent paper Olivier Hartmann reported a difference depending on the size of the ports (small ports characterized by a more public management, major national ports marked by greater private participation) and depending on the colonial past of maritime countries (a private participation stronger in countries of west Africa as a political organization influenced by a British colonial past). But the recent period (2007-2010) is characterized by the spread of port concessions and thus introduced into almost every port of private operators (Hartmann, 2010).

8 This change is moreover affecting the whole of Africa, which is becoming a theatre for competition between operators that are in a manner of speaking finishing the global 
shift towards terminalization. The most striking example is Dubai Ports World, which is present in Dakar (by winning the concession against competition from Bolloré and CMA-CGM), Maputo and Djibouti. It illustrates the changes that are being made to services to African seaboards by maritime and port operators (Maersk, MSC, CMA-CGM, CosCo, Dubai Ports World) whose strategy is centred on the newly dominant AfricaAsia route. A major change is that African ports are now highly oriented towards Asia. This applies even to those of West Africa (Chaponnière, 2010) where ports now have less container traffic with Europe $(640,000$ TEU in 2008) than with Asia (almost one million TEU in 2008). The activities of the shipping lines have changed accordingly. The Chinese companies COSCO and China Shipping and the Singaporean company Pacific International Lines have started to operate direct lines between the coast of West Africa and Asia. In 2007, Maersk-Sealand also started to operate a new route between the Far East and West Africa connecting the Malaysian ports of Port Kelang and Tanjung Pelepas (the Maersk group's Asian hub) and the ports of Lomé (Togo), Cotonou (Benin) and Apapa (Nigeria). The creation in 2011 of a new subsidiary, Bolloré Africa Logistics China, in order to improve logistical services between China and Africa also illustrates the new position African ports are taking up.

Figure 2 - The spread of port concessions

\begin{tabular}{|l|c|c|}
\hline PORTS & TERMINAL OPERATORS & TERMINAL CONCESSIONS \\
\hline Dakar & Dubai ports world & 2008 (25-year concession) \\
\hline Conakry & Bollore & 2011 (25-year concession) \\
\hline Abidjan & Bolloré/AP Moller (Maersk) & 2004 (15-year concession) \\
\hline Tema & Bolloré/AP Moller (Maersk) & 2007 (20-year concession) \\
\hline Lomé & MSC/GETMA & 2009 (35-year concession) \\
\hline Cotonou & Bollore & 2009 (25-year concession) \\
\hline Lagos (Tin Can) & Bollore & 2005 (15-year concession) \\
\hline Lagos (Apapa) & AP Moller (Maersk) & 2005 (25-year concession) \\
\hline Monrovia & AP Moller (Maersk) & 2010 (25-year concession) \\
\hline
\end{tabular}

Source: Port authorities, World Bank, 2011.

\section{A specific type of service: ports within their spaces}

The history of West African ports therefore at first sight illustrates their participation in the process by which operators are dividing ports into terminals that operate within integrated global networks. This change is a general one, but the practices involved must adapt to a specific spatial context. While the operator geography described above is founded on economies of scale and size which require port concentration, the general model must necessarily be modified to suit the characteristics of each space. In West Africa these characteristics have resulted in a two-stage process of change in services, which is leading to a new organization of the network of ports and which we shall examine below. 


\section{Stage one: the spread of a specific type of containerization (point- to-point services)}

The first stage is determined by the characteristics of the spaces that are served which make it impossible to apply strictly the concepts of port concentration and transhipment. The context of political and technical instability is the most striking of these characteristics. While it is true that the map of port traffic (Figure 3) shows the key features of the port range, it conceals the very considerable variability that has affected the traffic between ports in the last twenty years as a result of this context which may lead to the sudden closure of corridors. An extreme example of this is the two most recent crises in Côte d'Ivoire. The need to make use of alternative routes (as in the case of the crises in Togo in the 1990s and Côte d'Ivoire since 2000, when corridors were technically closed for the entire period...) means that operators cannot invest too heavily in a single hub and priority routes that serve the hinterland even if the port of Abidjan is a nodal point of the West African port range. This redistribution function and port concentration is thus limited by the context of instability. It also encourages operators to diversify their investments and keep their facilities simple, which also means they are suited to unbalanced freight flows with insufficient volumes to provide the economies of scale necessary to implement general containerization. The structural imbalance of West African economies thus results in an equation which is difficult for the shipping lines to solve.

Figure 3 - Port containers traffic in West Africa, 2009

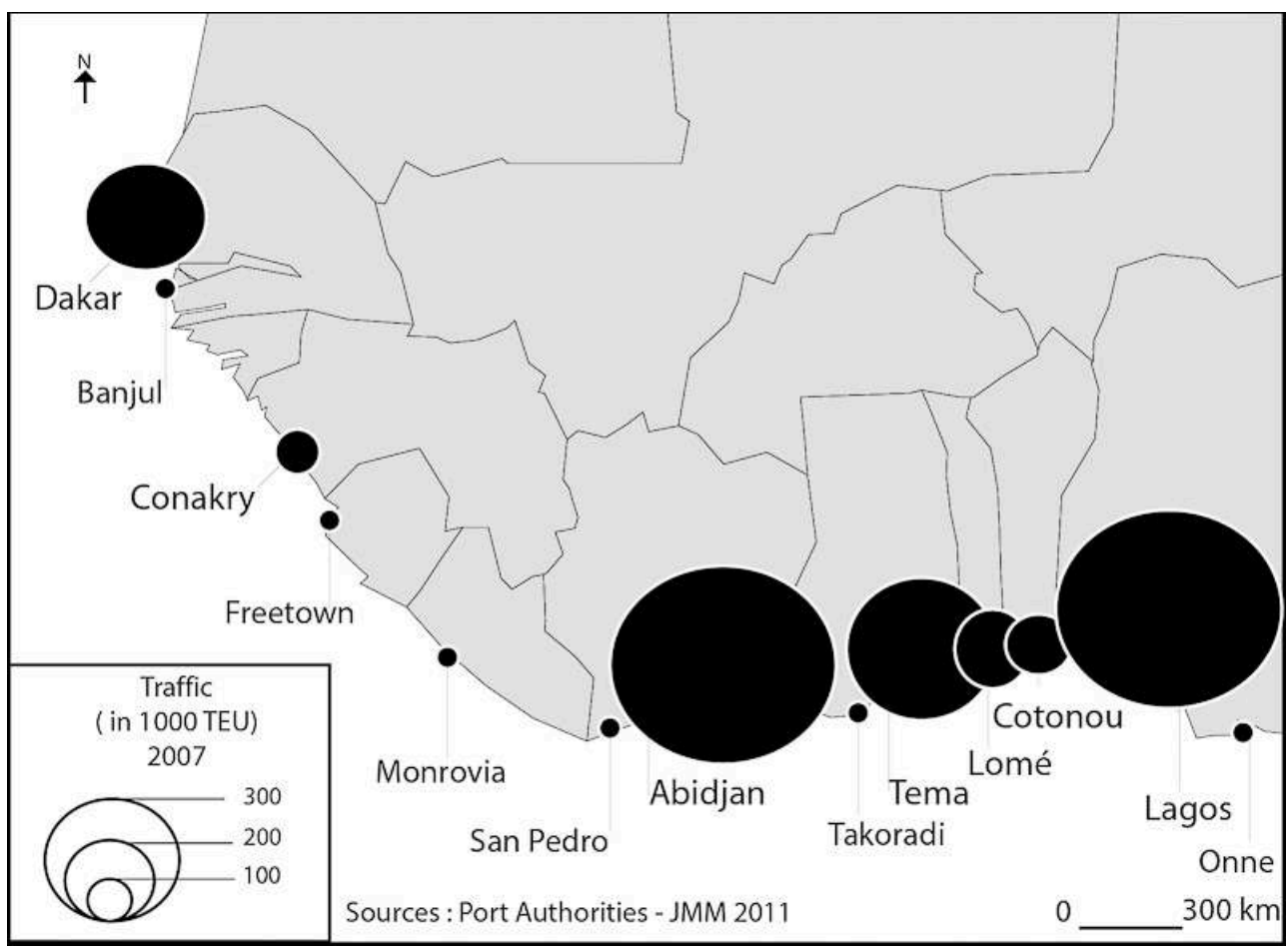

Source: Containerisation international, 2011.

11 This imbalance means that it is difficult to manage container flows which are full in the case of imports and empty in the case of exports. The low levels of port traffic in a marginal economic space means that at the same time it is difficult to make port calls 
profitable. West Africa therefore suffers from a combination of characteristics - and the presence of many other factors such as problems with customs and the low level of infrastructure investment - which oblige operators to adopt specific practices. Of course, indirectly, containerization is spreading along the West African coast, but in a way which is suited to the context. Services are linear (port by port) using that is known as "cabotage" without a high level of port concentration. In addition, the services in question use geared vessels (which handle the freight themselves) that can call at terminals that have no freight handling facilities.

\section{Second stage: the first signs of port concentration and the beginnings of a hub and spoke network}

12 A second stage is currently taking shape, which seems to foreshadow the emergence of a service model that is based on a higher degree of port concentration. It therefore heralds the beginnings of a partial hub \& spoke model. This new stage has been brought about by operators in a context in which port concessions for terminals are becoming the general rule. These new concessions result in competition between ports, made possible by the changing characteristics of the West African economy. The huge increase in direct foreign investment in Africa (250\% between 2002 and 2007), and the increase in African exports (37\% between 2005 and 2007) which is matched by a rise in imports of manufactured goods ( $34 \%$ in the same period too) have led to an unprecedented increase in port traffic. This growth in traffic which is accompanied by increasing containerization of bulk and semi-bulk goods (for example cotton, coffee and cocoa) in particular to Asia and more especially China (Chinese imports from Africa grew by $10 \%$ a year between 2000 and 2010), makes it possible for shipping lines to be managed in a new way. Maritime operators are showing increased interest in services to West Africa, all the more so in view of the overcapacity of the global fleet (due to the crisis of 2009). Competition is increasing between shipping lines and terminal operators in the calls for tender for port concessions and container terminals with gantry cranes are becoming widespread.

13 The operators are therefore placing West African terminals on the world stage. It is nevertheless true that most West African ports are mainly hinterland ports and transhipment accounts for only a small proportion of activities in what remains a context of recurrent instability. However, this proportion is on the increase and one can detect the beginnings of port concentration (Abidjan, Lagos) and redistribution to secondary ports. The considerable increase in transhipment traffic that occurred between 1995 and 2007 in Abidjan, in spite of the various crises, appears to be a sign of this, as does the arrival in July 2011 of a 4500 TEU Maersk-Sealand vessel on the line between Asia and West Africa which was processed at Abidjan and Lagos and increased capacity by $25 \%$. This development obviously remains at the mercy of a system which is unstable both politically (crisis in Côte d'Ivoire) and economically (the international crisis). The operators were deeply affected by the 2009 crisis which led to a period of uncertainty regarding scheduled investments. Nevertheless, the increase in port traffic has changed the geography of the network which is based on a process of terminalization permitting the familiar dual process of the concentration of shipping lines (Maersk-Sealand in Abidjan and Lagos, MSC in Lomé and perhaps COSCO in Onne). 
The West African ports system is finally characterized by a movement similar to other ports in Africa (increasing role of private operators, container traffic growth) but with a lower intensity of transshipment system. If recent statistics show the consolidation of the West African port system around a few ports (figure 4) oriented mainly to Asia, these ports are primarily associated with domestic national market (Nigeria, Ivory Coast, Ghana, Senegal). The traffic of transshipment to find on other african regions (Ducruet et al, 2011; Alix, 2011) in South Africa (Durban), North Africa (Tanger Med), East Africa (Djibouti-Doraleh) are lowest in West Africa where operators continue to connect the various ports in the logic of national service market (Hartmann, 2011). This organisation is based on the consolidation of port terminal operators (Dubai Ports in Dakar, Bolloré in Abidjan, Cotonou, Lagos, Conakry and Abidjan). The rapid development (between 2004 and 2010) of these port concessions also raises the issue of possible overcapacity in the context of the non-expandable West African market (Freire Matos, 2010) but also illustrates the advent of international operators from the private sector in the deregulated networks and the transposition of their practices to spaces with specific features.

Figure 4 - The growth of containerisation in the West African Ports

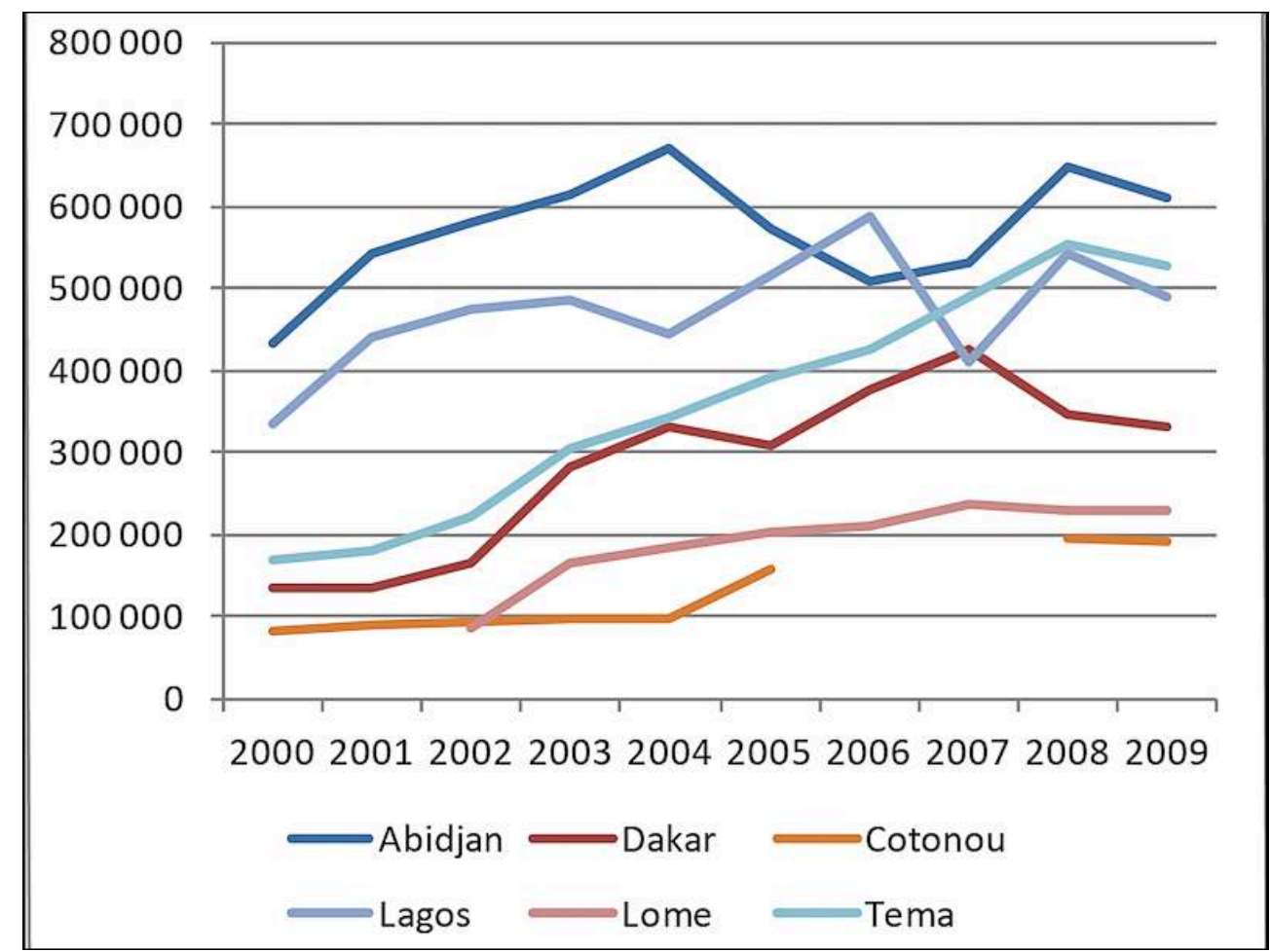

Source: Containerisation international 2011 \& Secafil/Yann Alix 2011.

\section{The trajectory of the port system in West Africa: what research question for geography?}

In a context of transport network deregulation and the spread of the port concession model, a large-scale re-organization of the interaction between the actors present in West African ports has been taking place. A new geography of private sector operators 
is gradually bringing West African terminals into the global network. The aim of this paper has been to explain the path of West African ports between global integration and regional particularities. This path introduces a final issue to develop in future research on the local impact of this new geography of operators. The local issue was not addressed in this paper. But it is this issue that emerges at the end of the reflection. The impact of this private investment on development in the region is difficult to observe in West Africa as elsewhere, because the international operators seek to dissociate the functions that are internal to the network (rationalizing the maritime network around hubs) and the external functions of the network (serving areas). Tension is therefore growing between the developing (global) networks and the permanent (local) spaces that are served. The "distortion" between services to spaces and network's rationalization observed by Jacques Guillaume (2001) and Benjamin Steck in the case of West Africa and its "nested marginalities" (1997) is becoming more accentuated. This distortion is not confined to Africa, it is universally present and is leading, to use Peter Hall's expression (2010), to disconnection between ports and areas which poses serious challenges to public action with regard to port policies. Although the problem is not limited to Africa, it is nevertheless more severe in countries where deregulation has been rapid and where expertise in the area of public action has been substantially cut. In addition, the move towards port concessions is part of a more general trend towards the introduction of concessions. The trend towards concessions also extends to industry, tourism and even urban areas and sometimes involves very large areas (Giraud, 2006), therefore raising the issue of the private enclaves and how they are linked to areas.

With regard to ports, we can thus ask a simple question: how does the process of port terminalization affect West Africa and in what way does it contribute to development? The increase in port concessions and private investment are responsible for modernizing port facilities in a way that is crucial for economic competitiveness. Achieving economies of scale in West Africa obviously has some positive impacts in terms of rationalizing the transport chain for economies which hitherto have suffered much due to the cost of transport. But we still need to see through future research whether this recent rationalization of the port system, which provides international operators with very large productivity increases and returns on investment, also benefits the economies of West Africa by improving port clearance and services to different areas, or if it merely benefits the networks of the companies involved.

\section{BIBLIOGRAPHIE}

Alix Y, 2011. Growing containerised trade between West Africa and European and Asian economies. UNCTAD, Trade Logistics Branch, Transport Newsletter $n^{\circ} 51,6 \mathrm{p}$.

Chaponnière JR, 2010. Le basculement de l'Afrique vers l'Asie. Enjeux pour les ports africains. Afrique Contemporaine, $\mathrm{n}^{\circ} 234$, p. 27-40. 
Debrie J, 2010. From colonization to national territories in continental west Africa : the historical geography of a transport infrastructures network. Journal of Transport Geography, vol 18, Issue 2, p. 292-300.

Ducruet C., Notteboom T, 2011. The worldwide maritime network of container shipping: spatial structure and regional dynamics. Globalization and world cities research networks, http:// www.lboro.ac.uk/gawc/rb/rb364.html

Fleming D.-K., Hayuth Y, 1994. Spatial Characteristics of Transportation Hubs: Centrality and Intermediacy. Journal of Transport Geography, n², p. 3-18.

Frémont A, 2007. Le monde en boîte : conteneurisation et mondialisation. Editions Lavoisier, 145 p.

Freire Matos A, 2010. L'évolution du paysage portuaire en Afrique de l'ouest : causes, impacts, pertinence. Mémoire du Master Transports Internationaux, Université Paris 1, 45 p.

Giraud F, 2006. Études comparées des politiques d'aménagement du territoire et de développement régional dans les pays du sud». Commande du Ministère des Affaires Étrangères, 135 p.

Gouvernal E., Lavaud-Letilleul V., Slack B. 2009. Transport and logisitics hubs: separating fact from fiction. International Workshop on integrating maritime transport in value chains, Montreal, Canada, 10-12 june 2009.

Guillaume J, 2001. Réseaux portuaires, segments de façades et recompositions régionales. Réseaux de transport, flux et recompositions régionales, actes des journées de la commission de géographie des transports, 5-6 septembre, p. 7-13.

Hall P, 2010. Maritime ports and the politics of reconnection. Transforming Urban Waterfronts: Fixity and Flow, Desfor, G, Laidley, J, Schubert, D, and Stevens, Q. (eds), Abingdon, Routledge, p. 17-34.

Hartmann 0, 2010. Comment les pays enclavés s'articulent-ils à la mondialisation. Afrique Contemporaine, $\mathrm{n}^{\circ} 234$, p. 41-58.

Hoyle B., Charlier J. 1995. Inter - port competition in developing countries: an East African case study. Journal of Transport Geography, vol 3, n², p. 87-103.

Le Mens C, 2011. Le défi du transport terrestre vers l'hinterland oust-africain. Mémoire du Master Transports Internationaux, Université Paris 1, $81 \mathrm{p}$.

Lombard J, 1999. Les difficultés et les ambiguïtés du Projet Sectoriel des Transports Malien dans la région de Kayes. Communication Colloque SITRASS V, Cotonou, 2-3-4 novembre, 16 p.

Mohamed-Chérif F., Ducruet C, 2011. Les ports et la façade maritime du Maghreb, entre intégration régionale et mondiale. Revue Mappemonde, $\mathrm{n}^{\circ}$ 101, http://mappemonde.mgm.fr/ num29/articles/art11103.html

Parola R., Veenstra AW. 2008. The spatial coverage of shipping lines and container terminal operators. Journal of Transport Geography, n 16(4), p. 292-299.

Steck B, 1997. Le paradoxe maritime de l'Afrique de l'ouest. Une problématique des marginalités emboîtées. Géographes associés, n 20, p. 79-87.

Slack B. 2005. Terminalisation of ports: an academic question? ». International Workshop on New Generation of port cities and their role in global supply chains, december, Hong-Kong, p. 20-30.

Taaffe E. J., Morrill R., Gould P., 1963. Transport expansion in underdeveloped countries: a comparative analysis. Geographical Review, 53-4, p. 503-529. 


\section{RÉSUMÉS}

L'évolution d'un système portuaire dépend de son insertion dans le réseau mondial maritime et de son inscription dans des espaces locaux et régionaux qui proposent des caractéristiques économiques, politiques et géographiques spécifiques. Entre évolutions générales portuaires et transpositions régionales, l'objectif de cet article est d'observer cette combinaison de caractéristiques dans le système portuaire ouest-africain. L'évolution de ce système s'inscrit dans une trajectoire d'insertion au réseau maritime mais qui implique une adaptation des opérateurs internationaux de transport aux caractéristiques de l'espace ouest-africain. Cette trajectoire portuaire dans l'espace régional permet de repérer une géographie d'opérateurs qui modifie les conditions de la desserte des territoires.

The changes that occur in a port system depend on how it is integrated within the global maritime network and its relationship with local and regional spaces with their specific economic, political and geographical characteristics. The aim of this paper is to observe how this combination of the general changes affecting ports and specific regional transpositions is affecting the port system of West Africa. The way the system is changing is part of process of integration within the maritime network, but also a process which requires international transport operators to adapt to the characteristics of the West African space. This changing role of ports in the regional space allows us to identify a geography of operators which modifies services to areas.

\section{INDEX}

Keywords : area, maritime, network, operator, port, West Africa

Mots-clés : opérateur, port, réseau maritime, territoire

Thèmes : Sur le Champ - Sur le Terrain

\section{AUTEUR}

\section{JEAN DEBRIE}

Jean Debrie, jean.debrie@ifsttar.fr, est Chargé de recherche, Université Paris Est, IFSTTAR, SPLOTT Il a publié récemment :

- Beyer A., Debrie J., 2011. Les temporalités urbaines et frontalières du port de Strasbourg : analyse géo-historique d'une relation fluviale ville-port. Revue Métropoles, $\mathrm{n}^{\circ} 10$, http:// metropoles.revues.org/

- Debrie J., 2010. From colonization to national territories in continental west Africa: the historical geography of a transport infrastructures network. Journal of Transport Geography, vol 18, Issue 2, p. 292-300.

- Debrie J., Comtois C., 2010. Une relecture du concept de corridors de transport : illustration comparée Europe/Amérique du nord. Les Cahiers Scientifiques du Transport, n58, p. 127-144. 